\title{
PROSPECTIVE TEACHERS' PERCEPTION OF ENGAGEMENT IN ACTIVE LEARNING THROUGH PEER TEACHING AND PEER ASSESSMENT
}

\author{
Muhammad Sarwar* \\ Shafqat Hussain ${ }^{* *}$ \\ Ashfaque Ahmad Shah ${ }^{* * *}$
}

\begin{abstract}
The study intends to investigate the perceptions of higher education students about their engagement in active learning through peerteaching and peer-assessment. A group of 22 students comprising nine female and thirteen males participated in the study. The researchers taught the course within six weeks, and then divided it amongst students through assignments. The students prepared it, discussed with researchers, shared and taught the assigned part of the course to their peers in the classroom in the presence of one of the researchers. The peers assessed the quality of presentation and mastery of the content and teaching skills of their peers against a given rubric. Three instruments namely: questionnaire, interviews and focussed group discussion were used to investigate students' perceptions. The analysis of data revealed that students felt actively engaged in their studies through peer teaching and peer-assessment. Moreover correlation between peer assessment and teacher assessment was also calculated. Peer teaching and peer assessment can be confidently used in higher education in Pakistan on condition that teacher as a supervisor is highly vigilant.
\end{abstract}

Keywords: engagement; active learning; peer teaching; peer assessment; teacher education

\footnotetext{
* Associate Professor of Education, University of Sargodha, Sargodha, Pakistan

** Assistant Professor of Education, GC University Faisalabad, Faisalabad, Pakistan

*** Assistant Professor of Education, University of Sargodha, Sargodha, Pakistan
} 


\section{Introduction}

Engaging students in their studies has been a challenge for educators (Klem \& Connell, 2004). Previous research shows that engagement of students in educational tasks can predict learning (Baker, Clark, Maier, \& Viger, 2008; Croninger \& Lee, 2001; Finn, 1989; Finn \& Rock, 1997; Fredricks, Blumenfeld, \& Paris, 2004; Greenwood, Horton, \& Utley, 2002; Jang, Reeve, \& Deci, 2010; Klem \& Connell, 2004; Marks, 2000). Conversely, disengagement can lead to disciplinary problems and low academic achievement (Croninger \& Lee, 2001; Finn \& Rock, 1997; Jang et al., 2010; Rumberger \& Rotermund, 2012). Teacher has a pivotal role in engaging students in active learning (Green et al., 2012; Jang et al., 2010; Skinner, Furrer, Marchand, \& Kindermann, 2008). Surprisingly, there is dearth of studies on engaging students in their studies. The main objective of the study was to explore the perceptions of prospective teachers regarding role of peer-teaching and peerassessment in enhancing academic engagement of students at higher education level. The research was led by question, whether, peer teaching and peer assessment if properly supervised can contribute to active learning at higher education level.

\section{Literature Review}

Active learning requires teachers to adopt a variety of teaching methodologies to focus on the engagement of students (Maitles \& McAlpine, 2012). The lecture-based instruction in universities is often unsuccessful for many reasons, including poor student attention, and too much material presented at one time (Archer, Francis, \& Mau, 2009). Active learning involves students more (D. L. Kane, 2007; Keyser, 2000; Wolfe, 2006), and they feel excited, mentally alert, and caught up in the learning experience (Hollingsworth \& Lewis, 2006; Wolfe, 2006).

Engagement refers to the quality and quantity of time and effort a student puts into his/her study (Baker et al., 2008; Lee, Chung, Rahmah, \& Lim, 2011; Reeve, Jang, Carrell, Jeon, \& Barch, 2004). Students attitude towards study and classroom environment influence engagement (Brewster \& Fager, 2000; Dunleavy \& Milton, 2009; Fredricks et al., 2004). Classroom environment depends on the teachers ability to manage classroom resources, syllabus and students (Carini, Kuh, \& Klein, 2006; Chapman, 2003; Coates, 2010; Jones, 2009; Lee, et al., 2011; Wang \& Holcombe, 2010). 
The term 'active learning' is often used in opposition to 'passive learning’ (Murray \& Brightman, 1996). Active learning process assists learners to engage in studies and it has a positive and lasting impact on learning (Hur \& Suh, 2012; Smyth, 2009; Stephen, 2006). Active learning environments are enormously used to engage students and enhance their learning (Bilda, Candy, \& Edmonds, 2007; Bork, 2000; Liang \& Sedig, 2009). Research shows that students remember $10 \%$ of what they read, $26 \%$ of what they hear, $50 \%$ of what they see and hear, and $90 \%$ of what they say as they do something (Felder \& Silverman, 1988; Stice, 1987). Good teachers continually search for ways to engage students actively in the learning (Jardine, 1997). Active learning needs to be used frequently (Smyth, 2009; Wolfe, 2006).

Peer teaching is the phenomenon whereby a student teaches the peers (Goldschmid \& Goldschmid, 1976). Peer teaching has been widely used in education generally to enhance students' engagement and learning (Maitles \& McAlpine, 2012; Secomb, 2008). Peer teaching benefits students by involving them into in-depth study of material, analysis, and selection of key concepts into one's own words in order to teach their fellows at higher education level (Ramaswamy, Harris, \& Tschirner, 2001).

In peer teaching students are engaged and motivated to help their peers, and as a consequence their achievement is enhanced (Maitles \& McAlpine, 2012). Students want greater independence and autonomy in their classroom learning than they often get (McIntyre, Pedder, \& Rudduck, 2005). Autonomy and role of teacher within limits improves students learning (Silins \& Mulford, 2002). The present study was conducted with the students of Master of Philosophy in Education. If practiced by prospective teachers, peer teaching helps them to become better teachers (Murray \& Brightman, 1996).

In peer assessment, students feel empowered, active, and responsible for their own learning (Zhang, 2012). In Pakistan, assessment is limited to examinations which are usually biased and sometimes unfair (Ali, Tariq, \& Topping, 2012). Research shows that old-fashioned system of assessment hinders active learning (L. Kane, 2004; Schwartz \& Webb, 2002). Assessment drives university teaching in Pakistan (Ali, Tariq, \& Topping, 2009; Davis, Kumtepe, \& Aydeniz, 2007). In peer assessment learning is enhanced by students' feedback (Vickerman, 2009). It is an alternative evaluation arrangement which empowers students to assess the quality of peers' work (Sadler, 2005; Wen, Tsai, \& Chang, 2006). Peer assessment demands certain level of critical thinking and critical thinking is also enhanced by peer assessment (Brew, Riley, \& Walta, 2009; Fallows \& Chandramohan, 2001). 
Peer assessment helps teachers to measure their assessment in the light of students assessment of their peers (Davis et al., 2007; Dochy, Segers, \& Sluijsmans, 1999). Moreover, peer assessment helps strengthen relationship among peers (Darling-Hammond, Hammerness, Grossman, Rust, \& Shulman, 2005). Peer assessment is effective in almost all the subjects and provides greater understanding of what to be learned and assessed (Langan \& Wheater, 2003; Pharo \& De Salas, 2009; Sivan, 2000; Thomas, Martin, \& Pleasants, 2011; Yorke, 2003). This brief review of related literature provides the background for present study which intends to investigate the perceptions of students about engagement in active learning of higher education students through peer-teaching and peer-assessment.

\section{Methodology}

\section{Research Design}

A group of 22 students, comprising 9 female and 13 males participated in the study. These students were enrolled in the 'Policy Studies' course that was offered in Master of Philosophy program.

The use of three different techniques improved the quality of data collected for exploring the perceptions. Triangulation improved the validity of collected data about student's perceptions of engagement in active learning through peer-teaching and peer-assessment. The context of the study was a Policy Studies course for students of Master of Philosophy in Education offered through department of education at University of Sargodha, Pakistan. Students were taught the course within six weeks, after that the course was distributed among them through assignments. They prepared their assignment, discussed it with teachers, shared with their fellows and then taught the assigned part of the course to their peers in classroom situation in the presence of one of the researchers. A rubric was used to assess the quality of presentation, mastery of the content and teaching skills of their peers. Three research tools (open ended questionnaire, interviews and focused group discussion) were employed to study students' perceptions about engagement in active learning through peer-teaching and peerassessment. Data regarding course content and organization, student contribution, learning environment and teaching methods, learning resources, quality of delivery and assessment were collected. 


\section{Peer-teaching Process}

The researchers taught the course in the first six weeks. The brief discussion of the course is often very effective before actual leaning (McIntyre et al., 2005). The course was divided into twenty two parts and each part was assigned to a student for teaching his/ her peers. The students were asked to prepare the assigned part of course and discuss it with peers and teachers within six weeks. After stipulated time the students taught their assigned part of the course to their peers in the presence of course leader. All students shared a copy of their pertinent part of the course with their fellows; in this way all students were able to have all course material.

\section{Peer-assessment Process}

The course teacher gave a brief description to the student about the peer evaluation rubric and process of peer evaluation. All the students were taken into examination hall along with the course material (prepared by students in parts) and they evaluated in keeping with the quality of course material prepared by their fellow students one by one against evaluation rubric. The participants also described in brief about evaluation rubric and process of evaluation. The assessors were also ascertained about anonymity of their assessments and were assured that their assessment would not be shared with anyone else. The students evaluated the work of each student against assessment rubric. The students also evaluated their own work. The purpose of conducting peer evaluation in the examination hall was to provide secure environment for peer evaluation to reduce peer pressure on assessment. The peer assessments were fed into the computer in the form of a matrix. This gave a glance about outliers in the assessments and probable positive or negative bias for any individual student (Falchikov \& Goldfinch, 2000). The written paper was conducted based on the course material developed by the students' collection of individual works.

\section{Instruments}

Qualitative data were collected after the completion of peerteaching, peer-assessment, written paper and declaration of results. Three instruments were used to collect data for triangulation purposes. Triangulation is the combination of methodologies to study the same 
phenomenon (Blaikie, 1991; Jick, 1979; Johnson \& Onwuegbuzie, 2004). Triangulation facilitates validation of data from more than two sources (Shaukat, 2011). In this study, triangulation was employed by questionnaire, interviews and Focus Group Discussion to explore the student's perceptions of engagement in Active Learning through peerteaching and peer-assessment at higher education level. Students' perceptions about 22 peers were taken through open ended course evaluation questionnaire. The questionnaire consisted of six open ended questions addressing following six areas: course content and organization, student contribution, learning environment and teaching methods, learning resources, quality of delivery and assessment. The researchers also conducted semi- structured interview with all 22 above said teacher educators one by one in office. The interview again addressed six areas mentioned in the questionnaire. The interview entailed students' perceptions about engagement in active learning through peer-teaching and peer-assessment at higher education level. In order to perform triangulation, Focus Group Discussion schedule was developed. Focus group discussion provides an effective method of collecting qualitative data (Twinn, 1998). Five focus group discussions were arranged with five members in two groups and four members in three groups. One of the researchers conducted the discussion and the other two noted down the main points. Immediately after every focus group discussion session, report of that session was written by three researchers before the next discussion session. In this study participants were asked to describe feelings about their engagement in Active Learning through peer-teaching and peer-assessment experience. Four Focus Group Discussions (six participants per FGD) were conducted (approximate time for one FGD was 60 minutes). The entire qualitative data collected through Focus Group Discussion has been given in a separate section.

\section{Results}

The data analysis has been set in four sections: scatter plots and regression analysis, analysis of data collected through questionnaire, analysis of data collected through interview, and analysis of data collected through Focused Group Discussion. 


\section{A) Scatter Plot and Regression Analysis}

The results of final paper marks conducted by the teachers and average peer-assessment were correlated and regression analysis was run. The results are as follows:

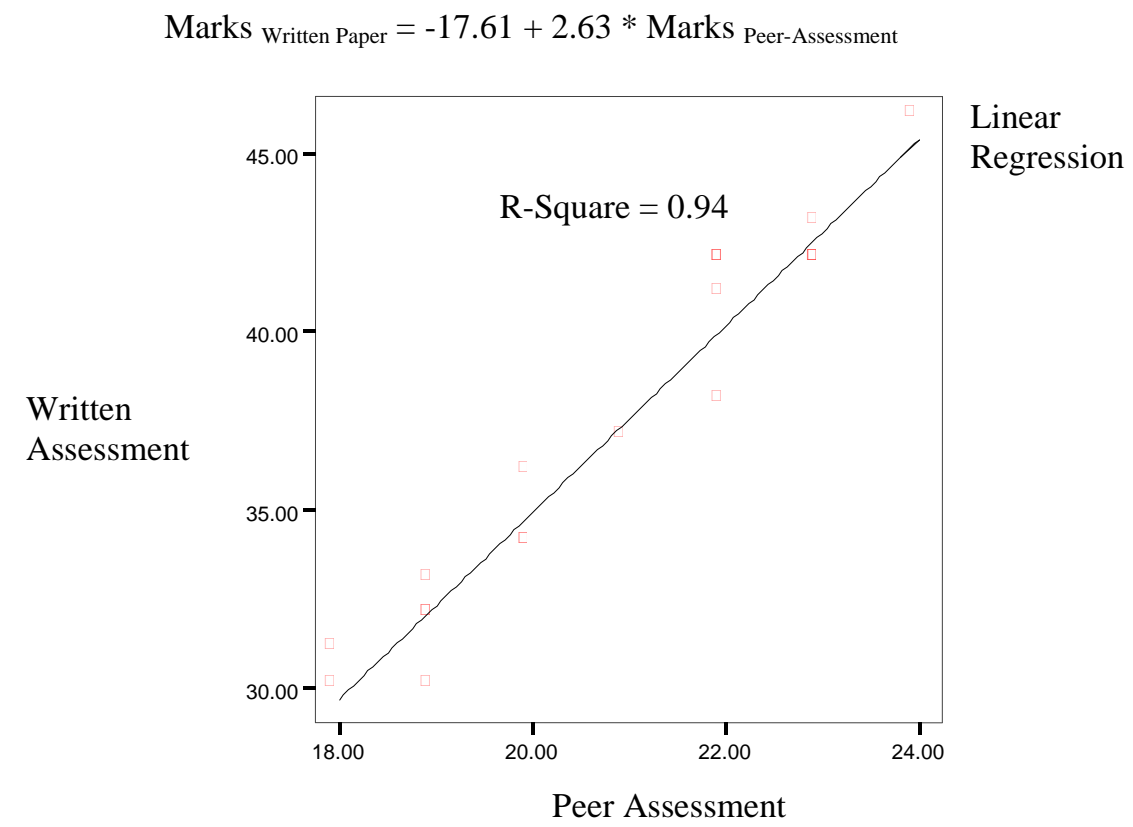

Figure 1. Scatter Plots between Written and Peer-assessment

\section{Regression Equations}

Marks $_{\text {Written Paper }}=$ Intercept + Coefficient $\left(\right.$ Marks $\left._{\text {Peer-Assessment }}\right)+$ error

Marks $_{\text {Written Paper }}=\alpha+\beta_{1}($ Marks Peer-Assessment $)+\varepsilon$

$\alpha=-17.61, \beta_{1}=2.63, \varepsilon=$ random error in measurement

Marks ${ }_{\text {Written Paper }}=-17.61+2.63 *$ Marks $_{\text {Peer-Assessment }}+$ error

Written paper marks were taken as marks scored by students in written test. Peer-assessment was taken as average marks given by peer 
to the student. While $\alpha, \beta 1$ are constants, $\varepsilon$ is random error in measurement. The values of constants are shown in able 2 below.

Table 1

Model Summary Peer Assessment Marks as predictor and Written Paper Marks as criterion variable

\begin{tabular}{ccccc}
\hline Model & $\mathrm{R}$ & $\mathrm{R}$ Square & Adjusted R Square & Std. Error of the Estimate \\
\hline 1 & $.971(\mathrm{a})$ & .943 & .940 & 1.24230 \\
\hline
\end{tabular}

Table 1 indicated that Peer-assessment marks explained 94\% variance in the written paper marks conducted by teachers.

Table 2

Coefficients of Regression Line presenting peer assessment marks as predictor and written paper marks as criterion variable

\begin{tabular}{ccccccc}
\hline Model & & $\begin{array}{c}\text { Unstandardized } \\
\text { Coefficients }\end{array}$ & $\begin{array}{c}\text { Standardized } \\
\text { Coefficients }\end{array}$ & t & Sig. \\
\hline B & Std. Error & Beta & B & $\begin{array}{c}\text { Std. } \\
\text { Error }\end{array}$ \\
1 & $\begin{array}{c}\text { (Constant) } \\
\text { Peer- }\end{array}$ & -17.608 & 3.116 & & -5.651 & .000 \\
& 2.626 & .147 & .971 & 17.807 & .000 \\
\hline
\end{tabular}

Table 2 indicates that peer-assessment marks can be used to predict written test marks at 0.05 levels of significance.

\section{B) Analysis of Data Collected through Questionnaire}

The open ended questionnaire used to collect data consisted of following six parts: course content and organization, student contribution, learning environment and teaching methods, learning resources, and quality of delivery and assessment.

\section{Perceptions about organization and management of the course}

The students observed that the course was well organized and was helpful in managing learning. The course started and ended as per 
schedule. The students learnt to assess peers performance and diagnose strengths and weaknesses. The group discussion was motivating and helpful. The students realized themselves to be more responsible and developed the habit of self and group study. One of the students, who had disturbed relationship with peers coupled with low achievement in previous semester, was of the view that the course would have been managed in much better way if students had not been involved.

\section{Perceptions about student contribution in the course}

The students realized that there was healthy competition and coordination among students. They worked hard during the course. The students contributed as a teacher, group member and assessor.

\section{Perceptions about learning environment in the class}

Learning environment was different from conventional classroom. The students felt more relaxed, disciplined, trustworthy, collaborative, innovative and active. Learning environment in the class was friendly, conducive, effective, cooperative and resourceful. The students shared their material, ideas and explanations. They learnt from their peers' mistake. Two students who were comparatively weak did not feel so happy with the situation.

\section{Perceptions about teaching methodology}

Peer teaching and learning was very effective way to learn which provided new ideas, improved confidence level of the students. Group discussion helped in socialization. It increased teamwork, resolved many conflicts, cleared concepts and improved deficiencies by removing false assumptions. Peer assessment was a very fine tool to assess the student. Some of the students mentioned that the process of grouping had negative effect on learning. One of the students showed his concern about bias in peer-assessment. He said that the assessment was very technical job and should not be done by the students. The student showed his reservations because he was the lowest achiever in peer-assessment, written paper as well as in previous semester.

\section{Perceptions about learning resources availability}

The general resources were available but facility of computer laboratory and multimedia were not sufficient. 


\section{Perceptions about quality of learning}

Most of the respondents (83\%) reflected that the quality of learning was very good while $9 \%$ were not satisfied with the quality of learning and $8 \%$ gave no comments.

\section{Students' Suggestions}

The respondents suggested that this method would be effective in the presence of the teacher. The teacher should provide more learning material. Strict schedule should be followed for making groups and completion of activities. The computer laboratory and library facilities need improvement. More coordination between students and teachers was suggested.

\section{C) Analysis of Qualitative Data Collected through Interview}

Analysis of data obtained through interviews is following. The interview consisted of six questions addressing six areas including: course content and organization, student contribution, learning environment and teaching methods, learning resources, quality of delivery and assessment.

\section{Course Content and Organization}

The students perceived that the course was well organized as the course leader conducted activities and delivered interactive lectures for clarification of course objectives. The objectives of the course were achieved.

\section{Student Contribution}

The students were engaged in teaching- learning process and assessing themselves and their peers. Hence they were fully engaged. One of the students said, "thank God, after all they (teachers) accepted that we could teach well." A respondent said with smiling face, "It was nice to have a teacher who should trust us to learn and teach at our own". The students enjoyed preparing specified part of the course and gained confidence while delivering it to their own class fellows. One of the students who remained shy in teacher's presence said, "It (teaching to class fellows) gave him opportunity to make his class fellows understand the depth of his knowledge."

\section{Learning Environment and Teaching Methods}

The students valued discussions, questions, arguments and counter arguments, hot debates, negotiate the meanings and merits/demerits of 
their ideas, and to develop understandings interactively. On asking about learning environment of the class a female student said' "It was good because students could express what they think. They could share their thinking, instead of being introvert, what they think of their ideas, what they think of other people's ideas.” On asking negatives points she replied, "Sometimes male students in their hot discussion forgot, where they were sitting and used harsh words and surface language, which embarrassed others." On asking solution to this problem, she replied, "we reminded them through class representative and they became increasingly conscious, so there was no need of teachers' intervention.” There was a good balance of lectures, peer tutoring, group discussions, and sharing of material. Physical facilities in classrooms were appropriate for group discussion and the entire class used to arrange them in a circle for discussion. One of the students commented, "the learning environment was $80 \%$ effective in this method while in other methods it is effective to only 50\%. I mean the environment was conducive.”

\section{Learning Resources}

Learning materials were developed by the students with the help of the teacher and were relevant, localized and useful. Every student had access to computer and Internet. One of the students commented, "learning material was available for every student at his/her seat. There was full production, distribution and discussion of material."

\section{Quality of Delivery}

Students commented that the course stimulated their interest and thinking process. One of the respondents said that "the course developed critical thinking in students and it would help them to become lifelong learners" similar results were reported by (Davies, 2009). When asked about their previous learning process one of them said, "The students used to be dependent on teacher to get information, even the alternative resources were there but the students were not confident enough to depend on those." Active learning contributes to long lasting learning (Clegg, 2000).

\section{Course Assessment}

Peer assessment gave students an opportunity for active engagement for assessment purposes. The feedback was immediate as peers and the teachers used discussion in each class. The assessment was more authentic as multiple tools and procedures were used for assessment. 


\section{D) Analysis of the Data Collected through Focus Group Discussion}

Focus groups discussion was conducted to explore in-depth perceptions and feelings of participants about engagement in active learning, peer-teaching and peer-assessment.

\section{Engagement in Active learning}

Participants observed that they were engaged in active learning as they get involved, concentrated and learned by doing .They feel more active and interested while participating in the course as compared to the courses taught by traditional method. Almost all participants were in favour of peer-teaching and peer-assessment in the institutions of teacher education to promote active learning. Peer teaching and peer assessment was effective for slow and fast learners; male and females; urban and rural students. The participants perceived that engagement in active learning through peer teaching and peer assessment helped students in clearing their concepts, increased learning, confidence building, positive competition, independent learning, accountability, independent work, confirmation of ideas, reduction of dropout, understanding among students, and developed more critical thinking.

In response to the question regarding involvement in traditional lecture method participants said that traditional method was characterised by no consultation with the students, less involvement, no innovation, boring, monotonous, no development of creative abilities and low level of achievement. One of the female participants stated, "during lectures most of the students send written messages to one another via cell phone and paper slips, do assignments of other subjects, and watch around / through the window and daydreaming."

\section{Peer Teaching}

Students perceived that peer-teaching improved self-confidence, cooperation, listening skills, teaching skills, creativity and experience sharing. It reduced hesitation and shyness. Peer teaching helped to overcome-weaknesses, understanding of concepts, positive competition and critical thinking. Some of the participants expressed concerns that peer teaching was time consuming and difficult to implement.

\section{Peer Assessment}

Participants perceived that assessing peers against a given set of criteria gave them a depth in understanding concepts. Assessment rubrics gave them indicators of good performance. One of the participant said "being well aware of peer's qualities we could assess them well”. One of the participant said, "After this process we could say that we were 
evaluators." The bias was the only concern, expressed by few participants. They expressed their view that some students may plan to favour or under-score fellow students. When asked about teachers' bias, they said that teachers were mature enough to evaluate but students were not.

\section{Discussion}

Strong positive correlation between peer assessment and teacher assessment provides evidence about the authenticity of using peerassessment at higher education level. The findings of other studies also support these results (opping, 1998). Peer assessment is an adequate reliability and validity (Ballantyne, Hughes, \& Mylonas, 2002; Dochy et al., 1999; Falchikov \& Goldfinch, 2000). Peer assessment can also contribute to reduce teachers' bias in assessment (Davies, 2009). The teacher's bias in assessment may be due to many reasons including over assessment of narrow content area (Frey, Schmitt, \& Allen, 2012). Peer assessment itself needs to be controlled for probable biasness due to personal liking and disliking (Kasanga, 2004). If properly used, peer assessment helps to develop content knowledge of students and they find it positive and interesting (Davies, 2009). This means that peer assessment can be used at university level to complement teacher's assessment of students' learning.

The respondents expressed that students' engagement in active learning through peer-teaching and peer-assessment method was new, unique, good, interesting, effective, more appropriate, easy to use, trustful, improved performance. It promoted group work and active learning. Referring to traditional lecture method, participants said that traditional method was characterised by no consultation with the students; less involvement, no innovation, boring, monotonous, no development of creative abilities and low level of achievement (Ali et al., 2009). The students felt positive change in their personality as mentioned by one of the respondents that active learning improved their personality and taught them ways to communicate with others in an acceptable and appropriate manner." Talking about its effectiveness, another student said that he has learnt an effective teaching method for implementation in his school. The concentration of students was also improved as expressed by a female respondent who said that her concentration always dispersed in lecture but she learnt more in active learning process. 
Regarding impact on learning, students expressed that their engagement in active learning through peer-teaching and peerassessment facilitated learning of new knowledge, generating new passion for learning and improvising the comprehension of concepts. It promoted effective learning styles from peers, autonomous learning and long lasting learning. Speedy and smooth learning, and learning through others' experiences helped slow learners to get maximum benefit.

Students' perceptions regarding classroom environment show that there is coordination and cooperation, learning friendly environment, engaged students, sharing of problems and their solutions. As mentioned by a respondent "students' engagement in active learning through peerteaching and peer-assessment was a powerful source to build the personality and change the behaviour.” They developed their teaching and assessment skills at the end of the course.

\section{Conclusion}

There was strong positive correlation between peer assessment and teacher assessment. This adds to dependability of peer assessment. The researchers conclude that peer assessment may be used at university level at least in complementarity to teacher assessment of their students' learning. Students' engagement in active learning through peer-teaching and peer-assessment at university level is found effective. Learning becomes more interactive, reflective, independent and autonomous. The students feel empowered and more confident in their learning; thus recognizing their growing maturity. The peer teaching gives them confidence and depth in knowledge, especially in local context. The students consider peer teaching and peer assessment helpful for improving their competence and confidence for learning. Fellow students actively listen and discuss with the dual purpose of learning and assessing.

\section{Recommendation}

It is recommended that peer teaching can be used as teaching under the supervision of highly vigilant teacher. It is further recommended that peer assessment can be used confidently in local university setting in Pakistan provided with highly vigilant supervisory role of the teacher. 


\section{REFERENCES}

Ali, A., Tariq, R. H., \& Topping, J. (2009). Students' perception of university teaching behaviours. Teaching in Higher Education, 14(6), 631-647.

Ali, A., Tariq, R. H., \& Topping, K. J. (2012). Perspectives of academic activities in universities in Pakistan. Journal of Further and Higher Education, 37(3), 321-348. doi: 10.1080/0309877x.2011.645454

Archer, L., Francis, B., \& Mau, A. (2009). 'Boring and stressful' or 'ideal' learning spaces? Pupils’ constructions of teaching and learning in Chinese supplementary schools. Research Papers in Education, 24(4), 477-497. doi: 10.1080/02671520802584111

Baker, J. A., Clark, T. P., Maier, K. S., \& Viger, S. (2008). The differential influence of instructional context on the academic engagement of students with behavior problems. Teaching and Teacher Education, 24(7), 18761883.

Ballantyne, R., Hughes, K., \& Mylonas, A. (2002). Developing procedures for implementing peer assessment in large classes using an action research process. Assessment \& Evaluation in Higher Education, 27(5), 427-441.

Bilda, Z., Candy, L., \& Edmonds, E. (2007). An embodied cognition framework for interactive experience. CoDesign, 3(2), 123-137. doi: 10.1080/ 15710880701251443

Blaikie, N. W. (1991). A critique of the use of triangulation in social research. Quality \& quantity, 25(2), 115-136.

Bork, A. (2000). Highly interactive tutorial distance learning. Information, Communication \& Society, 3(4), 639-644. doi: 10.1080/13691180010002116

Brew, C., Riley, P., \& Walta, C. (2009). Education students and their teachers: comparing views on participative assessment practices. Assessment \& Evaluation in Higher Education, 34(6), 641-657.

Brewster, C., \& Fager, J. (2000). Increasing student engagement and motivation: From time-on-task to homework: Northwest Regional Educational Laboratory Portland.

Carini, R. M., Kuh, G. D., \& Klein, S. P. (2006). Student engagement and student learning: Testing the linkages*. Research in Higher Education, 47(1), 1-32. 
Chapman, E. (2003). Alternative approaches to assessing student engagement rates. Practical Assessment, Research and Evaluation, 13(8).

Coates, H. (2010). Development of the Australasian survey of student engagement (AUSSE). Higher Education, 60(1), 1-17.

Croninger, R., \& Lee, V. (2001). Social capital and dropping out of high school: Benefits to at-risk students of teachers' support and guidance. The Teachers College Record, 103(4), 548-581.

Darling-Hammond, L., Hammerness, K., Grossman, P., Rust, F., \& Shulman, L. (2005). The design of teacher education programs. Preparing teachers for a changing world: What teachers should learn and be able to do, 390-441.

Davies, P. (2009). Review and reward within the computerised peer-assessment of essays. Assessment \& Evaluation in Higher Education, 34(3), 321-333. doi: 10.1080/02602930802071072

Davis, N. T., Kumtepe, E. G., \& Aydeniz, M. (2007). Fostering Continuous Improvement and Learning Through Peer Assessment: Part of an Integral Model of Assessment. Educational Assessment, 12(2), 113-135. doi: 10.1080/10627190701232720

Dochy, F., Segers, M., \& Sluijsmans, D. (1999). The use of self-, peer and coassessment in higher education: A review. Studies in Higher education, 24(3), 331-350.

Dunleavy, J., \& Milton, P. (2009). What did you do in school today? Exploring the concept of student engagement and its implications for teaching and learning Toronto: Canada Canadian Education Association.

Falchikov, N., \& Goldfinch, J. (2000). Student peer assessment in higher education: A meta-analysis comparing peer and teacher marks. Review of educational research, 70(3), 287-322.

Fallows, S., \& Chandramohan, B. (2001). Multiple approaches to assessment: reflections on use of tutor, peer and self-assessment. Teaching in Higher Education, 6(2), 229-246.

Felder, R. M., \& Silverman, L. K. (1988). Learning and teaching styles in engineering education. Engineering education, 78(7), 674-681.

Finn, J. D. (1989). Withdrawing from school. Review of Educational Research, 59(2), 117-142. 
Finn, J. D., \& Rock, D. A. (1997). Academic success among students at risk for school failure. Journal of applied psychology, 82(2), 221.

Fredricks, J. A., Blumenfeld, P. C., \& Paris, A. H. (2004). School engagement: Potential of the concept, state of the evidence. Review of Educational Research, 74(1), 59-109.

Frey, B. B., Schmitt, V. L., \& Allen, J. P. (2012). Defining authentic classroom assessment. Practical assessment, research \& evaluation, 17(2), 2.

Goldschmid, B., \& Goldschmid, M. L. (1976). Peer teaching in higher education: a review. Higher Education, 5(1), 9-33.

Green, J., Liem, G. A. D., Martin, A. J., Colmar, S., Marsh, H. W., \& McInerney, D. (2012). Academic motivation, self-concept, engagement, and performance in high school: Key processes from a longitudinal perspective. Journal of adolescence, 35(5), 1111-1122.

Greenwood, C. R., Horton, B. T., \& Utley, C. A. (2002). Academic engagement: Current perspectives on research and practice. School Psychology Review.

Hollingsworth, P., \& Lewis, G. (2006). Active learning increasing flow in the classroom (Vol. null).

Hur, J. W., \& Suh, S. (2012). Making Learning Active with Interactive Whiteboards, Podcasts, and Digital Storytelling in ELL Classrooms. Computers in the Schools, 29(4), 320-338. doi: 10.1080/07380569.2012.734275

Jang, H., Reeve, J., \& Deci, E. L. (2010). Engaging students in learning activities: It is not autonomy support or structure but autonomy support and structure. Journal of educational psychology, 102(3), 588.

Jardine, R. (1997). Active Learning Mathematics Histroy PRIMUS, 7(2), 115122. doi: $10.1080 / 10511979708965852$

Jick, T. D. (1979). Mixing qualitative and quantitative methods: Triangulation in action. Administrative science quarterly, 24(4), 602-611.

Johnson, R. B., \& Onwuegbuzie, A. J. (2004). Mixed methods research: A research paradigm whose time has come. Educational researcher, 33(7), 14-26.

Jones, R. D. (2009). Student Engagement: Teacher Handbook. New York: USA: International Center for Leadership in Education. 
Kane, D. L. (2007). Educators, learners and active learning methodologies. International Journal of Lifelong Education.

Kane, L. (2004). Educators, learners and active learning methodologies. International Journal of Lifelong Education, 23(3), 275-286.

Kasanga, L. A. (2004). Students' response to peer and teacher feedback in a first-year writing course. Journal for Language Teaching $=$ Tydskrif vir Taalonderrig, 38(1), p. 64-99.

Keyser, M. W. (2000). Active learning and cooperative learning: understanding the difference and using both styles effectively. Research Strategies, 17(1), 35-44. doi: http://dx.doi.org/10.1016/S0734-3310(00)00022-7

Klem, A. M., \& Connell, J. P. (2004). Relationships matter: Linking teacher support to student engagement and achievement. Journal of school health, 74(7), 262-273.

Langan, M., \& Wheater, P. (2003). Can students assess students effectively? Some insights into peer-assessment. Learning and Teaching in action, 2(1).

Lee, N., Chung, H. T., Rahmah, H., \& Lim, T.-M. (2011). The relationship between persistence, academic engagement and academic achievement among post graduate students Malaysia: Open University Malaysia.

Liang, H.-N., \& Sedig, K. (2009). Characterizing navigation in interactive learning environments. Interactive Learning Environments, 17(1), 53-75. doi: 10.1080/10494820701610605

Maitles, H., \& McAlpine, C. (2012). 'I've adopted a tiger': enhancing teaching and learning with infants through an active and integrated approach. Education 3-13, 40(5), 515-531. doi: 10.1080/03004279.2010.550587

Marks, H. M. (2000). Student engagement in instructional activity: Patterns in the elementary, middle, and high school years. American Educational Research Journal, 37(1), 153-184.

McIntyre, D., Pedder, D., \& Rudduck, J. (2005). Pupil voice: comfortable and uncomfortable learnings for teachers. Research Papers in Education, 20(2), 149-168.

Murray, R., \& Brightman, J. R. (1996). Interactive Teaching. European Journal of Engineering Education, 21(3), 295-308. doi: 10.1080/03043799608923415 
Pharo, E., \& De Salas, K. (2009). Implementing student peer review: Opportunity versus change management. Journal of Geography in Higher Education, 33(2), 199-207.

Ramaswamy, S., Harris, I., \& Tschirner, U. (2001). Student peer teaching: An innovative approach to instruction in science and engineering education. Journal of Science Education and Technology, 10(2), 165-171.

Reeve, J., Jang, H., Carrell, D., Jeon, S., \& Barch, J. (2004). Enhancing students' engagement by increasing teachers' autonomy support. Motivation and emotion, 28(2), 147-169.

Rumberger, R. W., \& Rotermund, S. (2012). The relationship between engagement and high school dropout Handbook of research on student engagement (pp. 491-513): Springer.

Sadler, D. R. (2005). Interpretations of criteria-based assessment and grading in higher education. Assessment \& Evaluation in Higher Education, 30(2), 175-194.

Schwartz, P. L., \& Webb, G. (2002). Assessment: Case studies, experience and practice from higher education: Routledge.

Secomb, J. (2008). A systematic review of peer teaching and learning in clinical education. Journal of clinical nursing, 17(6), 703-716.

Shaukat, S. (2011). Changes in Prospective Teachers' Self-efficacy Beliefs during Pre-service Teacher Education Programme. (Doctor of Philosophy), University of the Punjab, Lahore.

Silins, H., \& Mulford, B. (2002). Schools as learning organisations: The case for system, teacher and student learning. Journal of Educational Administration, 40(5), 425-446.

Sivan, A. (2000). The implementation of peer assessment: an action research approach. Assessment in Education: Principles, Policy \& Practice, 7(2), 193-213.

Skinner, E., Furrer, C., Marchand, G., \& Kindermann, T. (2008). Engagement and disaffection in the classroom: Part of a larger motivational dynamic? Journal of educational psychology, 100(4), 765.

Smyth, K. E. (2009). Enhancing the agency of the listener: introducing reception theory in a lecture. Journal of Further and Higher Education, 33(2), 131140. doi: 10.1080/03098770902856660 
Stephen, C. (2006). Insight 28, early years education: Perspectives from a review of the international literature (Vol. null).

Stice, J. E. (1987). Using Kolb's Learning Cycle to Improve Student Learning. Engineering education, 77(5), 291-296.

Thomas, G., Martin, D., \& Pleasants, K. (2011). Using self-and peer-assessment to enhance students' future-learning in higher education. Journal of University Teaching \& Learning Practice, 8(1), 5.

Topping, K. (1998). Peer assessment between students in colleges and universities. Review of educational research, 68(3), 249-276.

Twinn, D. S. (1998). An analysis of the effectiveness of focus groups as a method of qualitative data collection with Chinese populations in nursing research. Journal of Advanced Nursing, 28(3), 654-661.

Vickerman, P. (2009). Student perspectives on formative peer assessment: an attempt to deepen learning? Assessment \& Evaluation in Higher Education, 34(2), 221-230.

Wang, M.-T., \& Holcombe, R. (2010). Adolescents' perceptions of school environment, engagement, and academic achievement in middle school. American Educational Research Journal, 47(3), 633-662.

Wen, M., Tsai, C., \& Chang, C. (2006). Attitudes towards Peer Assessment: A Comparison of the Perspectives of Pre-Service and In-Service Teachers. Innovations in Education and Teaching International, 43(1), 83-92.

Wolfe, K. (2006). Active Learning. Journal of Teaching in Travel \& Tourism, 6(1), 77-82. doi: 10.1300/J172v06n01_05

Yorke, M. (2003). Formative assessment in higher education: Moves towards theory and the enhancement of pedagogic practice. Higher Education, 45(4), 477-501.

Zhang, A. (2012). Peer Assessment of Soft Skills and Hard Skills. Journal of Information Technology Education: Research, 11, 155-168.

Received on: January 07, 2015

Revised on: December 30, 2015

Accepted on: January 28, 2016 